\title{
In vitro Exopolysaccharide Production of Some Soil Bacteria Isolated from Soil Affected by Salt
}

\author{
Cigdem Kucuk
}

\section{ABSTRACT}

In this study, production of exopolysaccharide (EPS) from soil bacteria isolated from the salinity soil and the effects of agitation, some carbon sources such as glucose, fructose, xylose, rhamnose and $\mathrm{NaCl}$ levels the on production of polysaccharide playing a role in soil aggregation were studied. Maximum EPS production for Acinetobacter sp., Pseudomonas fluorescens and Sphingomonas paucimobilis was obtained $72 \mathrm{~h}$ of incubation and maximum EPS production for Bacillus simplex was obtained at $96 \mathrm{~h}$. Maximum EPS production was obtained at $150 \mathrm{rpm}$ for all bacteria studied. Glucose gave the best result for all of bacteria. Bacillus simplex produced higher EPS and viscosity than the other bacteria. $\mathrm{NaCl}$ levels affected both the growth and exopolysaccharide production of the bacteria. By promoting aggregate formation, EPS produced bacteria such as S.paucimobilis, B.simplex, Acinetobacter sp. and P.fluorescens may have created favorable growth.

Keywords: Agitation, carbon source, exopolysaccharide, soil bacteria, $\mathrm{NaCl}$
Published Online: July 16, 2020

ISSN: $2684-5199$

DOI : $10.24018 /$ ejbio.2020.1.4.56

\section{Kucuk*}

Harran University, Turkey.

(e-mail: ckucuk@harran.edu.tr)

\section{INTRODUCTION}

Exopolysaccharides produced by bacteria are a complex biofilm of high molecular polymers [1]-[3]. Exopolysaccharides (EPS) are involved in the formation of microbial aggregates, bioremediation, plant-microbe interaction and adhesion to surface [4], [5]. The production of EPSs by bacteria causes sand particle to adhere and build up an aggregate. EPS can protect the cells from various stressess such as temperature, $\mathrm{NaCl}$, drought, $\mathrm{pH}$ and provide with energy and carbon source in decreasing nutrient limiting conditions [6], [7]. The efficiency in conducing forced aeration is linked to agitation in culture. The carbon source plays a major role in the synthesis of polysaccharide by microorganisms [8].

Carbohydrates are an important source of nutrients for microorganisms. In order to identify a suitable carbon source for exopolysaccharide production by tested bacteria; different carbohydrates, i.e. glucose, fructose, xylose, rhamnose were used. Many bacteria such as Sphingomonas, Rhizobium, Pseudomonas, Bacillus and Streptococcus produces EPS. Also, Azotobacter vinelandii, A.chrococcum, Acetobacter xylinum, Burkholderia caribensis, Azospirillium have also been reported to produce EPS [7], [9], [10]. Some isolates of Bacillus species have been known to produce EPS such as levan, mannan and acidic polysaccharides [11]. EPSs have been largely studied for either understanding their role in the environment [12]-[14] or assessing their potential applications in the industrial applications [15]-[17].
The influence of EPS by producing rhizobacteria on the aggregation of root adhesing soils was demonstrated by Ashraf et al. [18]. It has been reported that EPS produced by soil bacteria is effective in the formation of rhizospheric soil aggregation and in determining the volume of macroporous soil [2]. Chenu and Guerif [19] reported that exopolysaccharides produced from bacteria are the molecules that increase the plasticity of clay and increased the mechanical strength of clay minerals. It has been reported that EPS produced by bacteria in the soil plays an important role in collecting soil around the roots and in the structural stability of the salt in the soil $[4,18]$. Harran Plain is one of the most important agricultural regions of Turkey and has a great potential for the major agricultural products of the Southeastern Anatolian in Turkey [20].

Harran Plain is important in Turkish agricultural production. Harran Plain has 225000 ha area and currently 132000 ha area is now irrigated. 15000 ha area have saline and sodicity problems due to excessive irrigation and poor drainage [20]. EPS production specifically important mechanism in salt affected soils. With regard to bacteria isolated from saline soil in Turkey, there is not such work. In this study, the effects of different carbon sources, $\mathrm{NaCl}$ and aeration on the exopolysaccharide production of bacterial isolates from soil affected by salt were investigated. 


\section{MATERIALS AND METHODS}

\section{A. Study Site and Soil Sampling}

The bacteria used in this study were isolated from soil affected by salt in the plain of Harran in Turkey. Some physiochemical characteristics of used soil were shown in Table 1. The soil management is irrigated. The soil samples were taken from cotton cultivated areas. Physical and chemical properties of the soil used in this study were determined in samples taken from 0 to $15 \mathrm{~cm}$ depth.

\section{B. Routine Soil Analysis}

After air-dried soil samples were sieved through a $2 \mathrm{~mm}$ sieve. The soil $\mathrm{pH}$ measured by $\mathrm{pH}$ meter, electrical conductivity measured by EC meter [21]. $\mathrm{CaCO}_{3}$ contents were determined by volumetric method [22]. Organic matter contents were determined by the wet oxidation method with $\mathrm{K}_{2} \mathrm{Cr}_{2} \mathrm{O}_{7}$ [23]. Texture, total nitrogen, $\mathrm{K}$ and $\mathrm{Na}$ contents were determined according to Martin and Reeve [22]. Some characteristics of the soil are given in Table I.

TABLE I: PHYSICAL AND CHEMICAL PROPERTIES OF THE SOIL USED

\begin{tabular}{|c|c|}
\hline Property & Value \\
\hline \multicolumn{2}{|c|}{ Particle size distribution } \\
\hline Sand $(\%)$ & 22.88 \\
\hline Silt (\%) & 24 \\
\hline Clay $(\%)$ & 53.12 \\
\hline Texture grade & Clay \\
\hline $\mathrm{pH}$ & 7.74 \\
\hline $\mathrm{EC}\left(\mathrm{dS} \mathrm{m} \mathrm{m}^{-1}\right.$ at $\left.25^{\circ} \mathrm{C}\right)$ & 2.45 \\
\hline Total N (\%) & 0.18 \\
\hline Available K (kg/da) & 97.2 \\
\hline $\mathrm{CaCO}_{3}$ & 21.6 \\
\hline Organic matter $(\%)$ & 1.14 \\
\hline $\mathrm{Na}^{+}(\mathrm{me} / 100 \mathrm{~g})$ & 2.06 \\
\hline
\end{tabular}

\section{Bacterial Identification}

The bacteria isolated were identified as described by Ashraf et al. [6]. Briefly, the isolates were classified into Gram negative and Gram positive according to Gram staining and identified by their fermentation pattern in the VITEC system (bioMerieux) using a VITEC biochemical cards.

\section{Culture Conditions for Exopolysaccharide Production}

The RCV medium $\left(\mathrm{MgSO}_{4} 7 \mathrm{H}_{2} \mathrm{O}, 0.1 \mathrm{~g} \mathrm{l}^{-1} ; \mathrm{CaCl}_{2} 2 \mathrm{H}_{2} \mathrm{O}\right.$, $0.1 \mathrm{~g} \mathrm{l}^{-1} ; \mathrm{FeSO}_{4} 7 \mathrm{H}_{2} \mathrm{O}, 0.022 \mathrm{~g} \mathrm{l}^{-1}$; EDTA, $0.02 \mathrm{~g} \mathrm{l}^{-1} ; \mathrm{ZnSO}_{4}$ $7 \mathrm{H}_{2} \mathrm{O}, 0.43 \mathrm{mg} \mathrm{l}^{-1} ; \mathrm{MnSO}_{4} \mathrm{H}_{2} \mathrm{O}, 1.30 \mathrm{mg} \mathrm{l}^{-1} ; \mathrm{Na}_{2} \mathrm{MoO} 42 \mathrm{H}_{2} \mathrm{O}$, $0.75 \mathrm{mg} \mathrm{l}^{-1} ; \mathrm{H}_{3} \mathrm{BO}_{3} 2.80 \mathrm{mg} \mathrm{l}^{-1} ; \mathrm{CuSO}_{4} 5 \mathrm{H}_{2} \mathrm{O}, 26 \mu \mathrm{g} \mathrm{l}^{-1}$; $\mathrm{CoSO}_{4} 7 \mathrm{H}_{2} \mathrm{O} 70 \mu \mathrm{g} \mathrm{l}^{-1} ; \mathrm{K}_{2} \mathrm{HPO}_{4}, 5.2 \mathrm{mM} ; \mathrm{KH}_{2} \mathrm{PO}_{4}$, $4.4 \mathrm{mM}$; $\mathrm{pH}$ 6.8) was used to determine the effects of carbon sources on bacterial EPS production [24]. Bacteria were grown $\left(10^{8}\right.$ $\mathrm{cfu} \mathrm{ml}^{-1}$ ) in RCV mineral medium containing $10 \mathrm{~g} \mathrm{l}^{-1}$ of either glucose, fructose, xylose and rhamnose at $28 \pm 2{ }^{\circ} \mathrm{C}$. Carbon sources were separately sterilized by filter and added to the cooled basal media.

\section{E. Viscosity Measurement}

Viscometer (NDJ-1 model, Soft optical instruments) was used to determine the viscosity in the growth media. The $\mathrm{pH}$ of the samples was determined using a $\mathrm{pH}$ meter.

\section{F. Effect of Agitation on EPS Production of Cells}

Modifications of agitation (50, 100, 150 and $200 \mathrm{rpm})$ were also made to study the influence of culture conditions on exopolysaccharide production.

\section{G. Effect of $\mathrm{NaCl}$ Levels on EPS Production of Cells}

The cultures were inoculated into RCV medium containing different concentrations of $\mathrm{NaCl}(0,50,100$ and $150 \mathrm{mM}$ $\mathrm{NaCl}(\mathrm{w} / \mathrm{v}))$ and incubated at $150 \mathrm{rpm}, 28{ }^{\circ} \mathrm{C}$. Optical density was measurement at $540 \mathrm{~nm}$ by spectrophotometer. The experiments was conducted in three replicates.

\section{H. Exopolysaccharide Determination}

After inoculation, broth cultures were incubated at $28{ }^{\circ} \mathrm{C}$ for $24 \mathrm{~h}$. Bacterial culture is boiled for $15 \mathrm{~min}$ at $100{ }^{\circ} \mathrm{C}$, cooled and TCA was added. The contents were vortexed, centrifuged for $30 \mathrm{~min}$ at $9000 \mathrm{rpm} 4{ }^{\circ} \mathrm{C}$. The ethanol was added to the supernatant, the supernatant was stored at $4{ }^{\circ} \mathrm{C}$ for 1 night, the content was centrifuged. The pellet was dissolved in pure sterile water and the phenol sulfuric acid method was applied [25]. To determine the amount of EPS, a standard curve was prepared using the phenol sulfuric acid method using glucose. The EPS amount was calculated using the standard curve [8].

\section{Statistical Analysis}

The results were statistically analysed by the JMP11, the treatments means were compared by Tukey's test $(\mathrm{p} \leq 0.05)$ and studied triplicated replications.

\section{RESUlTS AND DisCUSSION}

Acinetobacter sp., Bacillus simplex, Sphingomonas paucimobilis, Pseudomonas fluorescens were selected due to their high number in soil. They were identified as the Gram negative bacteria Acinetobacter sp., Sphingomonas paucimobilis, Pseudomonas fluorescens and the Gram positive bacteria Bacillus simplex. Databases using VITEC program, confirmed the isolates belonged to the Acinetobacter sp., Bacillus simplex, Sphingomonas paucimobilis, Pseudomonas fluorescens (Table II). All bacterial strains grow fast medium supplemented with 100 $\mathrm{mM} \mathrm{NaCl}$ (Table II).

Four strains secrete the enzymes protease and catalase. EPS production by Acinetobacter sp., B.simplex, S.paucimobilis, P.fluorescens were investigated for different carbon sources, incubation times $(24,48,72,96,120 \mathrm{~h})$ and agitation $(50,100,150,200 \mathrm{rpm})$ in pure culture medium. Preliminary incubation experiments were performed in order to determine the effect of incubation period on EPS by the bacteria. Samples were removed at intervals (24, 48, 72, 96 and $120 \mathrm{~h}$ ) and quantitative extraction of EPS was carried out. According to these results, maximum EPS recovery for Acinetobacter sp., P.fluorescens, S.paucimobilis was 312.4, 410.6 and $345.8 \mu \mathrm{g} \mathrm{ml}{ }^{-1}$, respectively. After of $72 \mathrm{~h}$ of incubation, EPS production by Acinetobacter sp., P.fluorescens and S.paucimobilis started to decrease. Maximum EPS recovery for B.simplex $\left(418.2 \mu \mathrm{g} \mathrm{ml}^{-1}\right)$ was obtained at $96 \mathrm{~h}$, and therefore were selected to evaluate EPS production in further experiments (Fig. 1). 
respectively in media containing glucose, xylose, rhamnose and fructose, respectively. In Bacillus simplex, maximum EPS amount at glucose was $1204 \mu \mathrm{g} \mathrm{ml}^{-1}$ (Table III). In P.fluorescens, maximum EPS amount at glucose and fructose were $824.2 \mu \mathrm{g} \mathrm{ml}^{-1}$ and $811.2 \mu \mathrm{g} \mathrm{ml}^{-1}$, respectively. In S.paucimobilis, maximum EPS amounts at glucose,

TABLE II: IDENTIFICATION AND SOME PROPERTIES OF BACTERIAL STRAINS ISOLATED FROM SALT AFFECTED SOIL

\begin{tabular}{ccccc}
\hline Isolate no & Identified as & $\begin{array}{c}\% \\
\text { similarity }\end{array}$ & $\begin{array}{c}\text { Salt } \\
\text { tolerance }\end{array}$ & $\begin{array}{c}\text { Capacity for } \\
\text { at } 37{ }^{\circ} \mathrm{C}\end{array}$ \\
\hline BHO1 & Bacillus simplex & 99 & + & + \\
\hline BHO62 & Acinetobacter $\mathrm{sp}$ & 99 & + & + \\
\hline BHO45 & $\begin{array}{c}\text { Sphingomonas } \\
\text { paucimobilis }\end{array}$ & 99 & + & + \\
\hline BHO78 & $\begin{array}{c}\text { Pseudomonas } \\
\text { fluorescens }\end{array}$ & 99 & + & + \\
\hline \hline
\end{tabular}

*highest salt concentration (100 mM) which didn't affect growth

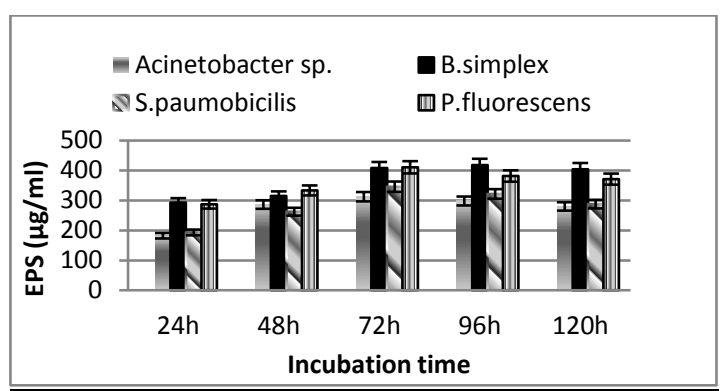

Fig. 1. Effect of incubation times on EPS production of tested bacteria. Error bars indicated Standard deviation of three paralel $(\mathrm{p} \leq 0.05)$.

Results for growth and EPS production of tested bacteria are shown in Table III. The growth and EPS productions of bacteria were affected by carbon sources (Table III). Carbon source is required for growth and EPS production of bacteria [26].

TABLE III: INFLUENCE OF CARBON SOURCES ON EPS PRODUCTION

\begin{tabular}{|c|c|c|c|c|}
\hline Bacteria & $\begin{array}{l}\text { Carbon } \\
\text { Sources }\end{array}$ & $\begin{array}{l}\text { Viscosity } \\
\text { (mPas) }\end{array}$ & $\mathrm{pH}$ & EPS $(\mu \mathrm{g} / \mathrm{ml})$ \\
\hline \multirow{5}{*}{$\begin{array}{l}\text { Acinetobacter } \\
\text { sp. }\end{array}$} & Glucose & 2.09 & 7.48 & $817.2 \pm 0$ \\
\hline & Fructose & 1.78 & 6.11 & $541.0 \pm 2$ \\
\hline & Xylose & 1.98 & 6.23 & $775.6 \pm 1$ \\
\hline & Rhamnose & 1.83 & 5.47 & $586.1 \pm 2$ \\
\hline & Control & 1.60 & 6.92 & $421.0 \pm 1$ \\
\hline \multirow{5}{*}{ B.simplex } & Glucose & 2.70 & 6.06 & $1204 \pm 2$ \\
\hline & Fructose & 2.22 & 7.08 & $688.4 \pm 1$ \\
\hline & Xylose & 2.36 & 6.24 & $987.0 \pm 0$ \\
\hline & Rhamnose & 2.40 & 5.66 & $1176 \pm 0$ \\
\hline & Control & 2.10 & 7.01 & $568 \pm 0$ \\
\hline \multirow{5}{*}{ S.paucimobilis } & Glucose & 2.35 & 7.04 & $951 \pm 1$ \\
\hline & Fructose & 2.21 & 7.81 & $743 \pm 1$ \\
\hline & Xylose & 2.32 & 6.21 & $652 \pm 2$ \\
\hline & Rhamnose & 2.28 & 6.02 & $874.2 \pm 1$ \\
\hline & Control & 2.11 & 6.83 & $371 \pm 1$ \\
\hline \multirow{5}{*}{ P.fluorescens } & Glucose & 2.02 & 7.04 & $824.2 \pm 1$ \\
\hline & Fructose & 1.83 & 7.81 & $811.2 \pm 0$ \\
\hline & Xylose & 2.17 & 6.21 & $745 \pm 2$ \\
\hline & Rhamnose & 2.00 & 6.02 & $692.8 \pm 2$ \\
\hline & Control & 1.78 & 6.46 & $386 \pm 0$ \\
\hline
\end{tabular}

* Values are the means \pm standard deviations of triplicate measurements

Acinetobacter sp. has produced $817.2 \mu \mathrm{g} \mathrm{ml}^{-1}, 775.6 \mu \mathrm{g} \mathrm{ml}$ 1, 586.1 $\mu \mathrm{g} \mathrm{ml} \mathrm{ml}^{-1}$ and $541 \mu \mathrm{g} \mathrm{ml} \mathrm{m}^{-1}$ exopolysaccharide rhamnose, fructose and xylose were $951 \mu \mathrm{g} \mathrm{ml}^{-1}, 874.2 \mu \mathrm{g} \mathrm{ml}$ ${ }^{1}, 743 \mu \mathrm{g} \mathrm{ml}^{-1}$ and $652 \mu \mathrm{g} \mathrm{ml}^{-1}$, respectively (Table III). EPS production may have been affected due to the nature of the carbon sources used. The results demonstrate that Acinetobacter sp., B.simplex, P.fluorescens and S.paucimobilis are capable of utilizing various sugars for EPS production. Glucose gave the best result for all of bacteria (Table III). Thus whether a sufficient supply of carbon sources was efficient for a EPS production seems to be dependent on the characteristics of the bacteria. Different microorganisms are reported to produce variety of exopolysaccharide [1], [2], [11], [27].

Tewari and Arora [7] reported about the utilization of glucose by Pseudomonas aeruginosa for EPS production. For the Rhizobium hedysarum isolate, glucose and sucrose were the most suitable source for EPS production [28]. The effect of agitation on viscosity and EPS production was observed in medium containing glucose (Fig. 2). Breedveld et al. [29] reported that the growth of microorganisms and increases in viscosities were dependent on aeration of the media. The growth of all bacteria and EPS production increased with the increase in agitation. However, the best EPS production was found at $150 \mathrm{rpm}$ for all bacteria (Fig 2). It has been reported that the Rhizobium isolate promotes polysaccharide synthesis when mannitol and sodium nitrate are added to the culture medium by forced agitation [8]. Several bacteria are known to synthesis large amounts of extracellular polysaccharides which resulting in mucoid colonies on agar plates and extremely viscous broth culture media [15], [30], [31]. In this study, the increase in agitation increased the viscosity (Fig. 2 ). These results are similar to those of other researchers [8], [32], [33].

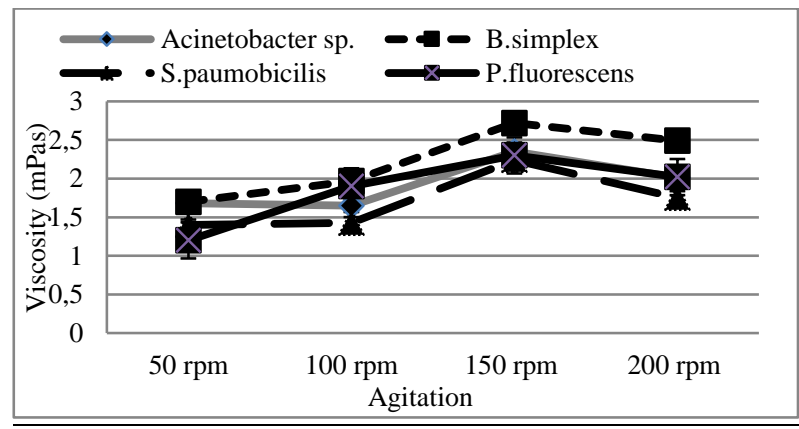

Fig. 2. Effect of agitation on viscosity of tested bacteria.

Tewari and Arora [7] found that the increase in EPS produced by Pseudomonas isolate was effective in protecting the isolate in soil. The production of EPS in bacteria is influenced by various environmental parameters such as temperature, salinity, pH [26]. The growth (Fig. 3) and EPS production of bacterial isolates were influenced by $\mathrm{NaCl}$ levels. Thus, EPS produced by bacteria as osmoprotective agent may protect bacteria from osmotic stress. 
Increase in EPS production in saline medium suggests that under stress condition energy flow of tested bacteria may be directed toward protective mechanism. Similar results have been examined in other studies [2], [34]. Maximum growth by these bacterial isolates was recorded with $100 \mathrm{mM} \mathrm{NaCl}$. $\mathrm{NaCl}$ concentrations $(50 \mathrm{mM}$ and $100 \mathrm{mM})$ in glucose containing medium have stimulated growth however, at concentration of $150 \mathrm{mM} \mathrm{NaCl}$, bacterial growths have decreased (Fig. 3). Salinity is a significant factor influencing the physiology of a microorganisms by affected nutrient uptake, enzyme activity [35]. In order to improve EPS production by bacterial isolates, the influence of $\mathrm{NaCl}$ was studied. The results of EPS production and growth were given in Table 4. As shown in Table 4, EPS amounts produced by bacteria were higher than their controls. Also a maximum EPS productions of tested bacteria were recorded with glucose and $\mathrm{NaCl}$.

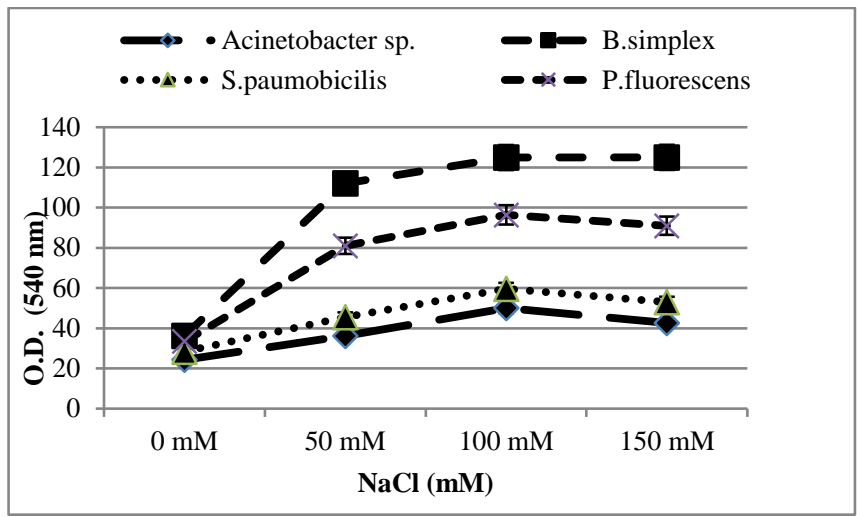

Fig. 3. Influence of $\mathrm{NaCl}$ levels on bacteria grown.

Geddie and Sutherland [12] reported that salinity alleviation due to EPS produced by bacteria may be attributed to $\mathrm{Na}^{+}$removal from the medium due to biosorption. Kang and Park [10] have been reported that the EPS produced by Acinetobacter sp. was increased with increase of $\mathrm{NaCl}$ concentration. The increase in the amount of salt was limited the increase in EPS production. In stress tolerating Bacillus simplex there was increase in EPS production by about, $139.2,123.8,117.1$ and $68.1 \%$ according to control, at glucose $+\mathrm{NaCl}(100 \mathrm{mM})$, fructose $+\mathrm{NaCl}(100 \mathrm{mM})$, xylose $+\mathrm{NaCl}(100 \mathrm{mM})$ and rhamnose $+\mathrm{NaCl}(100 \mathrm{mM})$, respectively (Table IV). Exopolysaccharides include molecules released by microorganisms in their nature environment and laboratory conditions $[9,26,30]$.

TABLE IV: INFLUENCE OF NACL (100 MM ) ON EPS PRODUCTION

\begin{tabular}{llcc}
\hline \hline Bacteria & \multicolumn{1}{c}{ Media } & $\begin{array}{c}\text { O.D. } \\
(\mathbf{5 4 0} \mathbf{~ n m})\end{array}$ & $\begin{array}{c}\text { EPS } \\
{ }^{*}(\boldsymbol{\mu g} / \mathbf{m l})\end{array}$ \\
\hline \multirow{4}{*}{ Acinetobacter sp } & Glucose $+\mathrm{NaCl}$ & 2.47 & $292 \pm 1$ \\
& Fructose $+\mathrm{NaCl}$ & 2.17 & $265 \pm 0$ \\
& Xylose $+\mathrm{NaCl}$ & 2.23 & $194 \pm 0$ \\
& Rhamnose $+\mathrm{NaCl}$ & 1.96 & $204 \pm 1$ \\
& Control $+\mathrm{NaCl}$ & 1.82 & $158 \pm 2$ \\
\hline \multirow{5}{*}{ B.simplex } & Glucose $+\mathrm{NaCl}$ & 2.54 & $421 \pm 0$ \\
& Fructose $+\mathrm{NaCl}$ & 2.23 & $382 \pm 0$ \\
& Xylose $+\mathrm{NaCl}$ & 2.18 & $292 \pm 1$ \\
& Rhamnose $+\mathrm{NaCl}$ & 2.43 & $394 \pm 1$ \\
& Control $+\mathrm{NaCl}$ & 2.09 & $176 \pm 1$ \\
\hline & Glucose $+\mathrm{NaCl}$ & 2.01 & $402 \pm 0$ \\
& Fructose $+\mathrm{NaCl}$ & 1.93 & $345 \pm 1$
\end{tabular}

\begin{tabular}{llll} 
S.paucimobilis & Xylose $+\mathrm{NaCl}$ & 1.65 & $366 \pm 2$ \\
& Rhamnose $+\mathrm{NaCl}$ & 1.98 & $213 \pm 2$ \\
& Control $+\mathrm{NaCl}$ & 1.70 & $152 \pm 2$ \\
\hline & Glucose $+\mathrm{NaCl}$ & 2.62 & $384 \pm 0$ \\
& Fructose $+\mathrm{NaCl}$ & 2.25 & $327 \pm 0$ \\
P.fluorescens & Xylose $+\mathrm{NaCl}$ & 2.10 & $286 \pm 1$ \\
& Rhamnose $+\mathrm{NaCl}$ & 2.04 & $184 \pm 1$ \\
& Control $+\mathrm{NaCl}$ & 1.67 & $165 \pm 1$ \\
\hline \hline
\end{tabular}

* $\overline{\text { Values are the means } \pm \text { standard deviations of triplicate measurements }}$

The EPS produced by Bacillus species and Enterobacter species seems to play a crucial role by binding the hazardous $\mathrm{Na}^{+}$, thereby alleviating the adverse effects of salts on crops [2]. As EPS can protect the bacterial isolates against abiotic stress [13], [34], we were interested in establishing a relationship between their growth, viscosity and EPS production.

Increase in EPS production in glucose and $\mathrm{NaCl}$ containing medium suggests that under stress condition energy flow of tested bacteria may be directed toward protective mechanism. Our results were similar to those of the researchers [2], [34]. The adaptation of bacteria to environmental conditions such as salinity, temperature, pressure, heavy metals and desiccation has been reported [12], [14], [34], [36], [37]. In this study, among carbon sources; glucose had greater influence on growth and EPS production (Table V).

TABLE V: THE EFFECTS OF VISCOSITY, EPS PRODUCED BY BACTERIA

\begin{tabular}{|c|c|c|c|c|}
\hline \multirow{3}{*}{$\begin{array}{l}\text { Carbon } \\
\text { sources }\end{array}$} & \multicolumn{4}{|l|}{ Properties } \\
\hline & \multicolumn{4}{|c|}{ Influence of $\mathrm{NaCl}$} \\
\hline & $\begin{array}{c}\text { Viscosity } \\
\text { (mPas) }\end{array}$ & $\begin{array}{c}\text { EPS } \\
(\mu \mathrm{g} / \mathrm{ml})\end{array}$ & $\begin{array}{c}\text { O.D. } \\
(540 \mathrm{~nm})\end{array}$ & $\begin{array}{c}\text { EPS } \\
(\mu \mathrm{g} / \mathrm{ml})\end{array}$ \\
\hline Glucose & $2.29 \mathrm{e}$ & $948.1 \mathrm{~d}^{*}$ & $2.41 \mathrm{~b}$ & $375.2 \mathrm{c}^{*}$ \\
\hline Fructose & $2.00 \mathrm{~b}$ & $694.9 \mathrm{~b}$ & $2.13 \mathrm{~b}$ & $322.3 \mathrm{~d}$ \\
\hline Xylose & $2.20 \mathrm{~d}$ & $791.0 \mathrm{c}$ & $2.05 \mathrm{a}$ & $284.4 \mathrm{c}$ \\
\hline Rhamnose & $2.13 \mathrm{c}$ & $832.3 \mathrm{~d}$ & $2.09 \mathrm{~b}$ & $246.4 \mathrm{~b}$ \\
\hline \multirow[t]{2}{*}{ Control } & $1.89 \mathrm{a}$ & $435.4 \mathrm{a}$ & $1.82 \mathrm{a}$ & $162.3 \mathrm{a}$ \\
\hline & \multicolumn{4}{|l|}{ Properties } \\
\hline \multirow[b]{2}{*}{ Bacteria } & \multicolumn{4}{|c|}{ Influence of $\mathrm{NaCl}$} \\
\hline & $\begin{array}{l}\text { Viscosity } \\
\text { (mPas) }\end{array}$ & $\begin{array}{l}\text { EPS } \\
(\mu \mathrm{g} / \mathrm{ml})\end{array}$ & $\begin{array}{c}\text { O.D. } \\
(540 \mathrm{~nm})\end{array}$ & $\begin{array}{l}\text { EPS } \\
(\mu \mathrm{g} / \mathrm{ml})\end{array}$ \\
\hline $\begin{array}{l}\text { Acinetobacter } \\
\text { sp. }\end{array}$ & $1.86 \mathrm{a}$ & $628.9 \mathrm{a}$ & $2.11 \mathrm{~b}$ & $222.8 \mathrm{a}$ \\
\hline B.simplex & $2.35 \mathrm{c}$ & $923.3 \mathrm{c}^{*}$ & $2.29 \mathrm{c}$ & $326.7 \mathrm{~d}^{*}$ \\
\hline S.paucimobilis & $2.25 \mathrm{~d}$ & $717.8 \mathrm{~d}$ & $1.86 \mathrm{a}$ & $292.9 \mathrm{c}$ \\
\hline P.fluorescens & $1.96 \mathrm{~b}$ & $691.3 \mathrm{~b}$ & $2.14 \mathrm{~b}$ & $270.1 \mathrm{~b}$ \\
\hline
\end{tabular}

Comparing different carbon sources, fructose containing medium showed the least effects on EPS production, whereas glucose containing medium was the most efficient $(\mathrm{p} \leq 0.05)$, followed by rhamnose, xylose (Table V). Comparing different bacterial isolates, EPS production by B.simplex was higher than others $(\mathrm{p} \leq 0.05)$. Also, EPS production at all carbon sources with and without $\mathrm{NaCl}$ was higher than their controls (Table V).

The highest EPS production according to control was examined by B.simplex in $\mathrm{NaCl}$ containing medium. B. simplex produced EPS and viscosity than the other bacterial isolates (Table IV). When bacterial cultures were grown in media containing different carbon sources, the EPS production and viscosity increased according to control medium (Table V). The lack of water in the soil is an important environmental stresses that limit the agricultural productivity [37]. The impact of exopolysaccharide on 
hydrology is a salient point and EPS can hold up to 20 times its own weight in water [36]. EPS can alter soil structure to mediate water retention hydraulic conductivity and aggregate sructure [4], [36].

\section{CONCLUSIONS}

In this study we examined the effects of salinity, agitaion and different carbon sources on EPS produced by Acinetobacter sp., Bacillus simplex, Spingomonas paucimobilis and Pseudomonas fluorescens. improving EPS soil produced by bacteria can be beneficial to plant growth and industry. EPS production by Acinetobacter sp., P.fluorescens, S.paucimobilis, B.simplex in culture could be beneficial to the soil bioremediation, plant growth promoting and industry. The results of this study provided the basis for the next experimental approach to investigate the exopolysaccharide production of bacterial isolates associated with soil aggregation and plant growth under saline conditions.

\section{REFERENCES}

[1] S. Cazrnes, P. D. Hallett, A.G. Bengough, and I. M. Yang. "Root an microbial derived mucilages affect soil structure and water transport". Eur J Soil Sci. vol. 51, pp. 435-443, 2000.

[2] S. K. Upadhyay, J. S. Singh, and D. P. Singh. "Exopolysaccharide producing plant growth promoting rhizobacteria under salinity condition", Pedosphere. vol. 21, pp. 214-222, 2011.

[3] T.T More, J.S.S. Yadav, S. Yan, R. D. Tyagi, and R.Y. Surampalli. "Extracellular polymeric substances of bacteria and their potentia environmental applications" Journal of Environmental Management. vol. 144, pp.1-25, 2014.

[4] N. Amellal, G. Burtin, F. Bartoni, and T. Heulin. 1998. "Colonization of wheat roots by EPS producing Pantoea agglomerans and its effect on rhizosphere soil aggregation," Appl Environ Microbiol. vol.64, pp. 3740-3747, 1998

[5] D.M. Mager, and A.D. Thomas. "Extracellular polysaccharides from cyanobacterial soil crusts: A review of their role in dryland soil processes," J Arid Environ. vol. 75, pp. 91-97, 2011.

[6] M. Ashraf, O. Berge, F. Azam, and T. Heulin. "Bacterial exopolysaccharides and productivity of salt affected soils. I. Diversity of exopolysaccharides producing bacteria isolated from the rhizosphere of wheat (Triticum aestivum L.) grown in normal and saline Pakistani soils," Pak J Biol Sci, vol. 2, pp. 201-206, 1998.

[7] S. Tewari, and N.K. Arora. "Multifunctional exopolysaccharides from Pseudomonas aeruginosa PF23 involved in plant growth stimulation, biocontrol and stress amelioration in sunflower under saline conditions", Curr. Microbiol. vol. 69, pp. 484-494, 2014.

[8] Ç. Küçük, and M. Kıvanç. "Extracellular polysaccharide production by Rhizobium ciceri from Turkey”, Annals of Microbiol. vol. 59, pp. 141144, 2009.

[9] C. Vanhaverbeke, A. Heyraud, and K. Mazeau. "Conformational analysis of the exopolysaccharide from Burkholderia caribensis strain MWAP71: impact on the interaction with soils", Biopolymers, vol. 69, pp. 480-497, 2003.

[10] Y. S. Kang, and W. Park. "Protection against diesel oil toxicity by sodium chloride-induced exopolysaccharides in Acinetobacter sp. strain DRI", J Biosci Bioengin. vol. 109, pp. 118-123, 2010.

[11] S. A. Razack, V. Velayutham, and V. Thangavelu. "Medium optimization for the production of exopolysaccharide by Bacillus subtilis using synthetic sources and agro wastes", Turk J Biol. vol. 37 , pp. 280-288, 2013

[12] J. L. Geddie, and I.W. Sutherland. "Uptake of metals by bacterial polysaccharides", J Appl Bacteriol. Vol. 74, pp. 467-472, 1993.

[13] E. Jofre, S. Fischer, V. Rivarola, H.G. Balegno, and G. Mori. "Saline stress affects the attrachment of Azospirillium brasilense $\mathrm{Cd}$ to maize and wheat root", Can J Microbiol., vol.44, pp.416-422, 1998.

[14] J. H. Suh, J. W. Yun, and D. S. Kim. "Effect of extracellular polymeric substances (EPS) on $\mathrm{Pb}^{2+}$ accumulation by Aureobasidium pullulans", Bioprocess Biosyst Eng. Vol. 21, pp. 1-4, 2013.
[15] D. Lobas, S. Schumpe, and W. D. Deckwer. "The production of gellan exopolysaccharide with Spingomonas paucimobilis E2 (DSM-6314). Appl Microbiol Biotechnol. vol. 37, pp. 411-415, 1992.

[16] C. Dupraz, and K. P. T. Vissher. "Microbial lithification in marine stromatolites and hypersaline mats", Trends Microbiol. vol.13, pp. 429438, 2005.

[17] P. Joshi, and A. Juwarkar. "In vivo studies to elucidate the role of extracellular polymeric substances from Azotobacter in immobilization of heavy metals", Environ Sci Technol. vol. 43, pp. 5884-5889, 2009.

[18] M. Ashraf, S. Hasnain, O. Berge, and T. Mahmood. "Inoculating wheat seedlings with exopolysaccharide producing bacteria restricts sodium uptake and stimulates plant growth under salt stress", Biol Fertil Soils. vol. 40, pp.157-162, 2004

[19] C. Chenu, and J. Guerif. "Mechanical strength of clay minerals as influenced by an absorbed polysaccharide", Soil Sci Soc Am J. vol. 55 pp. 1076-1080, 1991.

[20] M. A. Çullu, A. Almaca, A.R. Öztürkmen, N. Ağca, F. İnce, R. Derici, and A. Seyrek. "Harran ovası topraklarında tuzluluğun yayılma olasılığının belirlenmesi”, GAP BKİ Tarımsal Projeler Kesin Sonuç Raporu, Proje No: 4-1, pp.1-72, 2000. (in Turkish)

[21] D. L. Rowell. "Soil Science: Methods and Applications" Longman, Harlow, Essex; New York: Longman Scientific \& Technical; Wiley, ISBN 0-592-087848, 1994

[22] A. E. Martin, and R. Reeve. "A rapid manometeic method for determining soil carbonate", Soil Science, vol. 79, pp. 187-198, 1955.

[23] A. Walkey. "A critical examination of a rapid method for determining organic carbon in soils effect of variations in digestion conditions and of inorganic soil constituents", Soil Science. vol. 63, pp. 251-263, 1964

[24] T. Heulin, A. Guckert, and J. Balandreau. "Stimulation of roo exudation of rice seedlings by Azospirillum strains:carbon budget under gnotobiotic conditions", Biol Fertil Soils. vol. 4, pp. 9-11, 1987.

[25] M. Dubois, K. A. Gilles, J. K. Hamilton, P. A. Rebers and F. Smith "Colorimetric method for determination of sugars and related substanes", Anal Chem. vol. 28, pp. 350-356, 1956.

[26] U.U. Nwodo, E. Green, and A.L. Okoh. "Bacterial exopolysaccharides: functionality and prospects", Int. J. Mol. Sci. vol. 13, pp. 14002-14015, 2012.

[27] R. M. Banik, and A. Santhiagu. "Improvement in production and quality of gellan gum by Sphingomonas paucimobilis under high dissolved oxygen tension levels", Biotech Lett. vol. 28, pp.1347-1350, 2006.

[28] L. Navarini, M. Stredansky, M. Matulova, and C. Bertocchi. "Production and characterization of an exopolysaccharide from Rhizobium hedysari HCNT 1", Biotechnology Lett. vol. 19, pp. 1231 1234, 1997.

[29] M. W. Breedveld, L.P.T. Zevenhevizen, H.C.J. Conter-Cremes, and A.J.B. Zehnder. "Influence of growth conditions on production of capsular and extracellular polysaccharides by Rhizobium leguminosarum", Ant Leeuw Microbiol. vol. 64, pp.1-8, 1993.

[30] M. Aguilera, M.T. Quesada, V.G.A. Guila, J.A. Morillo, A.R Rivadeneyra, T. Cormenzana, and M.M. Sanchez. "Characterization of Paenibacillus jamilae strains that produce exopolysaccharide during growth on and detoxification of olive mill wastewaters", Bioresour Technol. vol. 99, pp. 5640-5644, 2008

[31] I. P. Sen, A.K. Mandal, R. Chakraborty, B. Behera, K.K. Yadav, T.K. Maiti, and S.S. Islam. "Structural and immonological studies of an exopolysaccharide from Acinetobacter junii BB1A", Carbohydrate Polymers. vol. 101, pp. 188-195, 2014.

[32] H. Dalton, and J.R. Postgate. "Effect of oxygen on growth of Azotobacter chroococcum in batch and continous culture", J Gen Microbiol. vol. 54, pp. 463-471, 1968.

[33] A. Elkines, E. Rosenberg, and E.Z Ron. "Production and secretion of polysaccharide biodispersan of Acinetobacter calcaaceticus A2 in protein secretion mutants", Appl Environ Microbiol., vol. 60, pp. 46424645, 1994.

[34] S. T. Pawar, A.A. Bhosale, T.B. Gawade, and T.R. Nale. "Isolation, screening and optimization of exopolysaccharide producing bacterium from saline soil", J Microbiol Res. vol. 3, pp. 24-31, 2013.

[35] H. H. Zahran. "Diversity, adaptation and activity of the bacterial flora in saline environments", Biology and Fertility Soils. vol. 25, pp. 211223, 1997.

[36] D. Or, S. Phutane, and A. Dechesne A. "Extracellular polymeric substances affecting pore-scale hydrologic conditions for bacterial activity in unsaturated soils", Vadose Zone Journal. vol. 6, pp. 298$305,2007$. 
European Journal of Biology and Biotechnology

www.ejbio.org

[37] M. A. Hanjra, and M.E. Qureshi. "Global water crisis and future food security in an aera of climate change", Food Policy. vol. 35, pp. 365377,2010 